\title{
Mobilização do Direito como Repertório de Ação Coletiva e Crítica Institucional no Campo Ambiental Brasileiro*
}

\section{Cristiana Losekann}

Professora adjunta de Ciência Política dos cursos de graduação e de pós-graduação em Ciências Sociais da Universidade Federal do Espírito Santo.

E-mail: cristianalosekann@gmail.com

\section{INTRODUÇÃO}

$\mathrm{D}$ esde a redemocratização brasileira, novas instituições, novos instrumentos de controle democrático e novas práticas têm surgido nas interações entre Estado e sociedade. Além das estruturas institucionais do Executivo, do Legislativo e do Judiciário, o Ministério Público ganhou autonomia adquirindo importância na defesa de direitos difusos e coletivos. Afora as institucionalidades, propriamente estatais, também se destacam as instituições híbridas (Avritzer e Pereira, 2005) caracterizadas pela abertura de espaços participativos e deliberativos compartilhados entre Estado e sociedade. Ainda como parte desse processo, em 1985 foi criada a Lei da Ação Civil Pública (ACP), um importante instrumento de acesso à Justiça disponível à sociedade civil.

No trabalho de investigação acerca dos processos de participação da sociedade civil na política ambiental, de forma geral, no Brasil, nas úl-

\footnotetext{
* Agradeço aos orientandos que colaboram no levantamento dos dados apresentados. Agradeço, também, a todos os entrevistados e aos integrantes do Comitê Articulador do Espírito Santo para a Cúpula dos Povos 2012 com os quais venho debatendo o tema tratado neste artigo. Devo agradecer, ainda, aos comentários e críticas recebidos ao paper preliminarmente apresentado no GT "Judiciário e política" durante o 36을 Encontro da Associação Nacional de Pós-Graduação e Pesquisa em Ciências Sociais (Anpocs).
}

DADOS - Revista de Ciências Sociais, Rio de Janeiro, vol. 56, no2 2, 2013, pp. 311 a 349. 
timas décadas, deparamo-nos com o uso direto da $\mathrm{ACP}^{1}$ e, de maneira menos formal, com os vínculos interpessoais estabelecidos entre militantes da sociedade civil e promotores e procuradores do Ministério Público. Em que pese esse endereçamento das lutas ao Judiciário - via direta ou através do Ministério Público - pudesse ser tomado como um tema para além do debate acerca da participação política, seria um equívoco deixar de perceber que esta também pode ser uma forma de participação. É uma maneira de encaminhar demandas ao Estado, mas através de diferentes formas de ação e lógicas institucionais. É necessário, de fato, admitir que as ações da sociedade civil no sentido da mobilização legal ${ }^{2}$ (Zemans, 1983) podem abrir novas possibilidades institucionais para decisões políticas. Segundo McCann (2010:182), “a mobilização do direito se refere às ações de indivíduos, grupos ou organizações em busca da realização de seus interesses e valores".

Mas, sobretudo, argumentamos que a crescente mobilização legal, no caso dos conflitos socioambientais, é um sintoma da dificuldade que o sistema representativo encontra para incorporar as agendas do ambientalismo em geral, principalmente quando ameaçam poderes econômicos com vínculos fortemente estabelecidos no sistema político brasileiro. Sintoma, também, da ineficiência e ineficácia de algumas instituições participativas que não são suficientes para incorporar tais demandas. Além disso, se analisarmos panoramicamente todos os mecanismos institucionais democráticos, podemos vislumbrar o processo de judicialização em questão como um processo de crítica institucional e tentativa de controle que pode gerar algum incremento democrático, ainda que seja necessário maior tempo de observação do fenômeno para gerar conclusões contundentes nesse sentido.

Para tal propósito adotamos uma perspectiva teórica que extrapola os contornos de uma específica teoria da democracia, mas que coloca o foco na análise de complexos e amplos processos de interação entre atores e instituições. Ou seja, uma abordagem que observa a relação entre distintos atores e formas de encaminhamentos das lutas políticas, e não em uma única lógica de participação. Não obstante, a unidade analítica passa a ser a ação política em processo. Porquanto, optamos pelos trabalhos de Sidney Tarrow e Charles Tilly e somamos esforços de tradução de suas bases conceituais aos casos analisados na conjuntura brasileira. Nossa expectativa é entender o que propicia, e como ocorre, o processo de mobilização legal, entendendo-o como parte de um repertório de ação coletiva usado pela sociedade civil $^{3}$ brasileira na in- 
tenção de influenciar os processos decisórios. Além disso, a análise das ações judiciais nos permite ampliar a compreensão dos conflitos ambientais existentes, percebendo quais são os atores e objetos de disputas na atual conjuntura.

Alguns trabalhos já foram elaborados acerca do uso da ACP tanto por parte da sociedade civil quanto do próprio Ministério Público (MP). Arantes (1999) enfatizou o protagonismo do MP evidenciando o baixo uso da ACP por parte da sociedade civil. Vianna, Burgos e Salles (2007) incluíram na análise o protagonismo do Judiciário sugerindo que uma "representação funcional" via ações judiciais recuperaria um déficit de representação gerado por outros poderes. Além destes, vários trabalhos no campo das Ciências Sociais têm discutido a crescente judicialização dos conflitos coletivos e o protagonismo emergente das instituições de Justiça no Brasil, sobretudo do Ministério Público. Assim, discutem-se entusiasticamente os efeitos desse protagonismo a partir de questões como "ampliação do acesso à Justiça", "judicialização da política" e "politização do Judiciário". Corroborando essas análises, outros pesquisadores argumentam acerca de um processo de elaboração de redes formais e informais que ligam o ativismo judicial com o militantismo político nas causas coletivas (Engelmann, 2006). Alguns são entusiastas, outros, mais céticos quanto ao ativismo do MP e do Judiciário. Ainda assim, pouco se pesquisou sobre as relações entre as instituições de Justiça e a sociedade civil.

Do ponto de vista das teorias dos movimentos sociais e da sociedade civil, recentemente, vários trabalhos têm apontado para as insuficiências destas teorias em compreender fenômenos contemporâneos observados nas relações entre Estado e sociedade, mormente, nos contextos latino-americanos. Entre as várias lacunas assinaladas, destacamos a hipossuficiência conceitual para explicar os vínculos interpessoais observados empiricamente entre sujeitos posicionados no Estado e sujeitos fora dele (Silva e Oliveira, 2011). Assim, somamos argumentos à proposta de análise de Abers e Bülow (2011), as quais, admitindo que nem sempre os vínculos entre movimentos sociais e Estado são prejudiciais aos primeiros, propõem "que as fronteiras organizacionais da nossa unidade de análise não deveriam ser definidas a priori, mas sim pelo formato das redes de ação coletiva que existem na prática" (ibidem:54). Sendo assim, o conceito de "repertório" nos parece um ponto de partida promissor. 
O artigo apresenta, portanto, uma caracterização da mobilização do direito enquanto um repertório de ação coletiva no campo ambiental brasileiro. Além disso, propõe uma explicação causal, relacionando este repertório com as instituições participativas especificamente, e levando em consideração, ainda, as características de um amplo contexto institucional e de mobilização social. Evidentemente, com este artigo não se esgota o tema, ao contrário, espera-se abrir uma extensa agenda de pesquisa desde sua dimensão empírica até suas implicações teóricas.

A dimensão empírica está fundamentada na apresentação de dados produzidos a partir de pesquisa sobre a judicialização como estratégia da sociedade civil na defesa do meio ambiente ${ }^{4}$. Buscamos identificar o grau do uso da ACP por parte das associações civis de forma direta, e os vínculos estabelecidos com o Ministério Público, na proposição de denúncias de danos ambientais. Buscou-se, também, ter um panorama dos principais temas, questões e aspectos socioambientais em conflito nestas localidades. Além disso, com fins de aprofundamento, analisamos no caso específico do Espírito Santo os canais de participação existentes e as formas através das quais a sociedade civil elabora suas estratégias de ação até chegar à articulação com o Ministério Público e o Judiciário.

Na intenção de caracterizar a mobilização do direito, enquanto repertório de ação coletiva, foram utilizados métodos quantitativos e qualitativos. A pesquisa, inicialmente, pretendia abarcar toda a região Sudeste, contudo, teve seu recorte limitado pela disponibilidade dos dados empíricos. Os dados quantitativos referem-se ao Estado do Espírito Santo (ES) e à cidade do Rio de Janeiro (RJ). Construímos um banco de dados das ACPs a partir das informações disponibilizadas pela Procuradoria da República no Espírito Santo e pela 1ạ Promotoria de Tutela Coletiva de Meio Ambiente e Patrimônio Cultural da Capital (MPRJ). Buscamos dados, também, a partir da consulta à jurisprudência disponível no site do Tribunal de Justiça do ES e do Tribunal de Justiça do RJ. Para a categorização que apresentamos, consultamos os registros online de cada ação judicial registrada nos respectivos tribunais ${ }^{5}$. Cabe ressalvar, contudo, que devido à inexistência de um mecanismo homogêneo para levantamento das ações judiciais não se pôde ler o quantitativo apresentado como sendo relativo ao universo total das ações em curso ${ }^{6}$. Contudo, as múltiplas estratégias de busca e o próprio volume das ações sugerem que tenhamos chegado muito próximos do quantitativo total. 
Para a análise que estabelece uma relação causal entre as instituições participativas e o recurso judicial, empregamos uma metodologia qualitativa, aprofundando o caso do Espírito Santo. Embora este não seja o estado que apresenta o maior quantitativo de ACPs, sua análise permite compreender como a mobilização do direito torna-se um repertório de ação coletiva e sua relação com as instituições participativas. Com tal propósito de investigação realizamos uma entrevista semidirigida com um analista ambiental do Instituto Chico Mendes de Conservação da Biodiversidade; três entrevistas semidirigidas com representantes da sociedade civil; sete questionários com representantes da sociedade civil; cinco entrevistas semidirigidas com procuradores da República e promotores de Justiça; análise do conteúdo de documentos e das próprias ações judiciais ${ }^{7}$.

Apesar de a pesquisa fundamentar-se em dados de duas localidades específicas, é de suma importância explicitar as possibilidades de generalização das evidências e conclusões propostas na análise em questão. Em primeiro lugar, como buscaremos mostrar, a chamada "judicialização dos conflitos ambientais" constitui-se como um fenômeno já identificado na literatura em outras regiões brasileiras (Pinto, 2012). Em segundo lugar, os aspectos institucionais analisados enquanto fatores causais existem de forma bastante uniforme em todo o Brasil sugerindo, a priori, certas condições semelhantes que oportunizam o fenômeno observado. Em terceiro lugar, do ponto de vista da mobilização do direito como repertório de ação coletiva, reunimos através de documentações - como panfletos, sítios da Internet e publicações da própria sociedade civil - diversas referências sobre o uso da ação judicial pelo Brasil afora. Nesta documentação encontram-se referências a litígios em regiões como Pará, Rondônia, Rio de Janeiro, Bahia e Espírito Santo. Nestes conflitos, variadas organizações, movimentos e comunidades locais relacionam-se com promotores de Justiça impetrando ações judiciais e, inclusive, mobilizando um grande empenho de controle e acompanhamento dos processos (Pinto, 2012). Além desses estados, o Paraná também desponta no quantitativo dos casos de judicialização. Reunindo várias organizações civis que têm caráter advocatício, como a organização "Terra de Direitos", encontramos facilmente muitos exemplos que sugerem um elevado uso da ação civil pública por proposição direta de associações. A organização Amarnatureza, por exemplo, reúne pelo menos $50 \mathrm{ACPs}$ de sua proposição desde o final da década de 1990 neste estado ${ }^{8}$. 
Portanto, o processo de judicialização de conflitos socioambientais não é prerrogativa de uma única localidade. Nos últimos anos tem sido observado um aumento na judicialização dos conflitos socioambientais no Brasil. De acordo com o relatório anual da 4a Câmara de Coordenação e Revisão da Procuradoria Geral da República, de 2009 para 2010 o registro de procedimentos ${ }^{9}$ que passam pelo Ministério Público, no Brasil, teve um aumento de $80,2 \%$. Apesar de ser um fenômeno geral, os dados da 4a Câmara apontam que a região Sudeste é a que mais promove ACPs e denúncias ao MP, o que corrobora a relevância dos casos que analisamos.

\section{A AÇÃO JUDICIAL COMO REPERTÓRIO DE AÇÃO COLETIVA}

Segundo Tilly, a ação coletiva se dá a partir de "repertórios" entendidos como "as maneiras através das quais as pessoas agem juntas em busca de interesses compartilhados" (Tilly apud Tarrow, 2009:51). Repertórios são limitados (e inovados) por fatores relacionados ao contexto estrutural e cultural os quais, acrescenta Tarrow (2009), produzem oportunidades e restrições políticas para a ação. Sendo assim, quando destacamos as "estratégias" e "vínculos" percebidos nas lutas do ambientalismo brasileiro, a ação judicial, o contexto institucional (que envolve desde as instituições de Justiça, as representativas e as participativas) e os padrões de interação observáveis entre sujeitos num dado processo político (promotores de Justiça, militantes, políticos etc.) constituem-se como elementos formadores de repertórios de ação - aspecto sugerido por Tilly e Tarrow para analisar o confronto, denominado "ação coordenada" (Tilly e Tarrow, 2007:32). Em nosso caso, esses elementos, quando mobilizados de certa maneira, têm gerado um processo de encaminhamento dos conflitos ambientais às instituições de Justiça.

É preciso compreender que o referido processo é iniciado quando há uma percepção dos atores de que a arena judicial pode ser acionada. Esse acionamento ocorrerá de duas formas: entrando diretamente com uma ACP ou realizando uma denúncia ao Ministério Público que pode ingressar ou não com uma ACP. Mesmo que o conflito seja resolvido sem a entrada em cena do Judiciário, através de um Termo de Ajustamento de Conduta (TAC), por exemplo, permanece essa possibilidade, no caso do descumprimento do acordo. Assim, a possibilidade de acionar o Judiciário tem um efeito de enforcement, ou de "ameaça", nas próprias palavras de ambientalistas. O efeito do poder institucional do Ju- 
diciário existe, portanto, mesmo quando o conflito não chega de fato a ser decidido nessa esfera. Neste caso, haverá ainda um efeito simbólico (McCann, 2010). Quando esse processo se repete ao longo de um período, torna-se um repertório de ação.

Tilly elaborou o conceito de "repertório" relacionando-o à ação coletiva na década de 1970 (Tilly, 1977). Inicialmente, enfatizou seus limites e esteve mais preocupado com a criação de uma tipificação. Com o decorrer dos anos o próprio autor tratou de modificar o conceito e ampliar sua teorização, enfatizando mais seu aspecto dinâmico e fluido ${ }^{10}$. Assim, em obras mais recentes, o autor afirmou que repertórios são construídos por performances, que têm certa fluidez - metaforicamente, ele faz a contraposição da fluidez do jazz e da comédia "dell'arte" ao ritual mais rígido de ler uma escritura sagrada (Tilly, 2006:454). Mas, ainda assim, os repertórios de performances não são infinitos, tampouco surgem do nada. Desde a formação dos Estados, a sociedade tem criado variadas formas de endereçar demandas a este (Tilly, 2008). Igualmente, performances diversas, como as barricadas, protestos, petições, publicações e, inclusive, as ações judiciais existem, isoladamente, há bastante tempo. Mas o que as torna repertório de confronto político é o fato de estarem relacionadas entre si, em termos práticos e de elaboração mental, compondo reivindicações e lutas políticas. Desta forma, a utilização do recurso judicial pode ser observada desde a sua possibilidade fática, contudo, o que a torna um repertório de ação coletiva é seu enquadramento dentro de um contexto mais amplo de lutas.

Para caracterizar repertórios, é necessário compreender que eles são oportunizados por variados fatores de ordem estrutural ou conjuntural, mais ou menos formais. Ademais, também sofrem restrições. Para Tilly e Tarrow, os "repertórios variam de lugar para lugar, época a época, caso a caso. Mas, em geral, quando pessoas realizam reivindicações coletivas, inovam dentro de um conjunto limitado pelos repertórios já estabelecidos para o seu lugar, tempo e caso" (2007:16; tradução livre).

Não obstante, desde sua elaboração inicial, Tilly deu ao conceito de repertório um sentido relacional, interativo e contingencial (Bringel, 2012:46). Sendo assim, concebeu que repertórios mudam, desaparecem e surgem, ou são inovados, por novas performances e/ou articulações de performances (cf. Tilly, 1978:2008). Este último aspecto é aquele que interessa para nossa discussão. 
A caracterização contingencial dos repertórios introduz, ainda, o elemento temporal para a análise, permitindo a compreensão de distintos momentos da ação coletiva, assim como suas relações causais. Na esteira desta linha de investigação Tarrow (ibidem) sugeriu que são "janelas de oportunidade" que possibilitam o surgimento de uma ação coletiva que se torna um repertório. Dentre as dimensões de oportunidade que o autor vislumbra, percebemos, em nosso caso, algumas janelas de oportunidades que coincidem à sua proposta conceitual, quais sejam: a existência da ampliação de acesso à participação da sociedade; a existência de aliados influentes e de disputa entre elites. No lugar daquilo que o autor caracterizou como "força do Estado" preferimos entender como o fator, diversidade institucional ${ }^{11}$.

Nosso argumento é de que a abertura dessas "janelas" oferece incentivos à mobilização legal, articulando distintas performances de ação coletiva. No que se refere à ampliação de acesso, nota-se a criação da própria Lei da ACP a qual permite, desde o final dos anos 1980, que associações civis de proteção ambiental, além do próprio MP, entrem diretamente com a ação judicial. Com relação à existência de aliados influentes, evidenciam-se as relações informais entre atores da sociedade civil e promotores e procuradores, além de juízes ativistas e outros burocratas que viabilizam informações ou manifestam apoio às demandas ambientais. O poder da influência desses é óbvio na medida em que detêm posições institucionais que lhes garantem legitimidade de enforcement, sobretudo, no caso do Judiciário (Ostrom, 1999; Keck e Hochstetler, 2007; McAllister, 2008). Como afirma Maciel (2011), as normas legais também constrangem ou incentivam a ação estratégica dos atores, o que torna o direito um recurso estratégico de ação. Ademais, temos que admitir o protagonismo conjuntural do Judiciário na revisão de decisões tomadas por outros poderes. Este fator contribui para gerar disputa entre as elites no poder e também fomenta a percepção da sociedade civil de que é possível reverter uma decisão já tomada pelo poder público, entrando com uma ação judicial.

Outra janela de oportunidade política aberta se refere à diversidade do próprio Estado que, através de suas instituições, pode ser percebida no Brasil de várias formas. Conforme elaborou O'Donnell (2011), a heterogeneidade do Estado se dá de forma vertical ou horizontal. No sentido vertical, a diversidade é relativa ao federalismo em suas várias escalas de decisão do nível nacional ao municipal. Já a diversidade horizontal é relativa à divisão dos três poderes, somando-se, de forma im- 
portante, a existência e a autonomia do MP. À heterogeneidade das ordens institucionais podemos incluir, ainda, as instituições híbridas (Avritzer e Pereira, 2005) participativas, que têm ganhado um peso grande nos processos de tomada de decisão.

Sendo assim, atores podem perceber que há viabilidade de deslocar suas ações de uma escala municipal para nacional, e que podem deslocar suas ações entre as aberturas ou "porosidades" das distintas ordens dos poderes. Nesses deslocamentos combinam-se formas de cooperação e de confronto. O acionamento de ordens ou escalas institucionais distintas também ocorre através de incentivos específicos e conjunturais, como a percepção de inefetividade ou ineficácia das instituições executivas, legislativas e participativas. A percepção que as pessoas têm acerca das instituições é um fator relevante para a ação. Mas a crença de que há fundamento para uma ação judicial necessita mais do que um simples descontentamento com uma situação, a contrariedade precisa ser elaborada enquanto uma injustiça ${ }^{12}$ (Gamson, 1992). E fundamenta-se na afirmação de direitos existentes e que, de alguma forma, estão sendo descumpridos. Isto pode ser compreendido através daquilo que Tarrow reconheceu como fatores que também são relevantes para a ação coletiva, as "estruturas de mobilização" e os "quadros interpretativos" (frames). Estes tornam um determinado repertório mais provável (preferível) a outro.

O conceito formulado por Snow e Benford (1988) tem a inspiração nos "esquemas de interpretação" de Goffman (1974) e possibilita compreender como as percepções e ações dos atores relativas à vida social alinham-se e produzem "cenários" ou conjunturas de significações. Para os autores, a formação destes "quadros" mobiliza adeptos potenciais, para angariar apoio e para desmobilizar antagonistas (Snow e Benford, 1988:198). Mas sugerem também que os quadros de ação coletiva não se formam simplesmente da junção de indivíduos e seus ideais, mas sim no compartilhamento sempre negociado das ideias e ações. Este aspecto, elaborado por Gamson (1992), permite observar como uma situação é compreendida como uma "injustiça". Nessas conformações, certas situações vividas são elaboradas como injustiças, e também são identificados antagonistas e aliados. Mas é importante frisar o caráter contingencial e dinâmicos destes frames. Eles seriam como "fotografias" de conjunturas relacionais, podem dissolver-se quando alguns elementos são alterados. 
Examinamos os dois conceitos de forma conjunta através da análise das características dos atores da sociedade civil mobilizados e dos "fluxos da ação" entre Estado e sociedade. Além disso, analisamos como os quadros de "injustiça ambiental" são construídos na ação coletiva, gerando uma interpretação característica aos conflitos em questão.

Naquilo que se refere à percepção de injustiça, sugerimos que há um alargamento da compreensão da temática "ambiental". Ademais, observa-se um debate que articula as posições Norte-Sul, numa reedição do tema do colonialismo. Ressalta-se que esse último fator encontra um elemento adicional fundamental no caso específico do Espírito Santo, qual seja, a existência factual de diversos empreendimentos de multinacionais causadores de grandes impactos. Esse fato será fundamental para a elaboração do antagonismo que servirá como força motriz à mobilização - capaz de minimizar diferenças entre as identidades e criar uma interpretação da existência de um inimigo comum às lutas. Na relação com o grande capital de exploração estrangeiro haverá um reconhecimento de igual posição de subalternidade (Sul-Norte) permitindo a expansão da rede num sentido transnacional (Keck e Sikkink, 1998). Isto explica as redes como Articulação Internacional dos Atingidos pela Vale do Rio Doce; Fórum dos Atingidos por Petróleo e Gás; Rede Alerta Contra o Deserto Verde etc.

Com relação àquilo que estamos chamando de "fluxos da ação", compreendemos que os mesmos são decorrentes do processo de identificação de afinidades de luta entre atores multiposicionados na sociedade e no Estado. Ou seja, certas lutas atravessam atores posicionados no Estado e na Sociedade. No caso do ambientalismo isso é bastante evidente e tem sido elaborado de formas distintas por vários autores. A formação das instituições de meio ambiente no Estado brasileiro esteve, desde o início, fortemente ligada ao ambientalismo da sociedade civil (Oliveira, 2008; Keck, 2007; Alonso, Maciel e Costa, 2007). Além disso, a criação de leis específicas de juizados especiais de meio ambiente irá contribuir com o surgimento de grupos temáticos de ativistas especializados (Engelmann, 2006). O próprio MP, em 2008, criou a "Rede Latino-Americana de Ministério Público Ambiental" constituída por vários países desta região. Assim, compartilham, se não visões de mundo, pelo menos, incentivos de ação. É assim que, em muitos casos, perceberemos militantes da sociedade civil agindo em concerto com promotores e procuradores engajados. 
Este último aspecto traz novos elementos para a discussão sobre dinâmicas de contestação e/ou cooperação, mas também para temas caros à teoria da sociedade civil, como as questões referentes à autonomia e à cooptação. A observação dos "fluxos de ação" sugere que não é possível compreender as relações entre Estado e sociedade de maneira dicotômica. Ambos são heterogêneos e ambivalentes, caracterizados por elementos concorrentes e em disputa. Como veremos, a seguir, a heterogeneidade do Estado abre oportunidades para novos repertórios de ação.

\section{JANELAS DE OPORTUNIDADE: ALIADOS INFLUENTES E DIVERSIDADE INSTITUCIONAL}

Segundo Tarrow, "o confronto aumenta quando as pessoas obtêm recursos externos para escapar da submissão e encontram oportunidades para usá-los. Ele também aumenta quando as pessoas se sentem ameaçadas por custos que não podem arcar ou que ofendem o seu senso de justiça" (ibidem:99). Assim, vários são os elementos que explicam a formação de um repertório de ação coletiva. No caso da judicialização dos conflitos socioambientais, a explicação parte, inicialmente, do grande e forte arcabouço jurídico o qual constitui a legislação ambiental brasileira (McAllister, 2008; Keck e Hochstetler, 2007). Nossa Constituição de 1988 estabelece o "direito ao meio ambiente ecologicamente equilibrado" inclusive para as futuras gerações. Desde a Lei Federal no 6.938/81, que estabeleceu a Política Nacional de Meio Ambiente, não apenas uma série de garantias foi fundamentada, mas também um grande aparato institucional de controle e garantias foi projetado e a participação da sociedade civil, amplamente prevista. Existem possibilidades, que vão desde a participação em conselhos, audiências e consultas públicas até a possibilidade de propor uma ACP.

Para corroborar, pesquisadores estrangeiros, como McAllister, têm entendido que "entre os países latino-americanos, o Brasil tem sido o mais inovador em edificar a capacidade de enforcement ambiental" (Jensen, 2010:27; tradução livre). A autora tem salientado os elevados poderes de controle que a lei brasileira atribuiu aos promotores públicos, além de constatar o alto grau de ativismo destes na sua função. A estrutura e autonomia do MP brasileiro também é reconhecida como rara e altamente responsável por gerar efetividade à lei ambiental ( $i b i-$ dem). Sendo assim, naquilo que se refere às oportunidades geradas 
pela abertura de acesso institucional, podemos, sem grandes hesitações, admitir que esta oportunidade política existe.

Os dados do nosso levantamento dispostos na tabela abaixo corroboram essa ideia inicial:

Tabela 1

Proponentes das Ações Judiciais por Localidade

\begin{tabular}{l|c|c|c}
\hline Proponente & $\begin{array}{c}\text { Cidade do Rio } \\
\text { de Janeiro (\%) }\end{array}$ & $\begin{array}{c}\text { Espírito Santo } \\
\mathbf{( \% )}\end{array}$ & $\begin{array}{c}\text { Total } \\
\mathbf{( \% )}\end{array}$ \\
\hline Sociedade Civil* & 12,7 & $0,9 \%$ & 13,6 \\
MPF & 0,1 & 6,6 & 6,7 \\
MP Estadual & 57,1 & 4,2 & 61,3 \\
MP Estadual e Prefeitura & 0,8 & 0 & 0,8 \\
Órgão Ambiental e de Patrimônio & 0,4 & 0,4 & 0,8 \\
Executivo Municipal & 8,2 & 0,3 & 8,5 \\
Executivo Estadual & 1,6 & 0 & 1,6 \\
MPF e Órgão Ambiental & 0 & 0,3 & 0,3 \\
Empresa Privada & 0,3 & 0 & 0,3 \\
Não encontrado & 5,7 & 0,4 & 6,1 \\
\hline Total de casos & $\mathbf{6 8 9}(\mathbf{8 6 , 9 \%}) * *$ & $\mathbf{1 0 4}(\mathbf{1 3 , 1 \% ) * * *}$ & $\mathbf{7 9 3} \mathbf{( 1 0 0 \% )}$ \\
\hline
\end{tabular}

Fonte: Elaboração própria a partir de consulta às ações judiciais nos Tribunais de Justiça do ES e RJ e Justiça Federal do ES.

* Na categoria chamada "sociedade civil" incluímos as ações propostas por associações civis, conselhos populares, populares representados pela Defensoria Pública e pessoas que impetraram ações populares. Resolvemos considerar as ações populares sem distinção às ações civis públicas porque na leitura destas ações observamos que a maioria destas acaba convertendo-se em ACP por determinação de juiz.

** Dados relativos às ACPs em curso em 2012. Esta informação aplica-se a todas as tabelas.

*** Dados relativos às ACPs em curso entre 2004 e 2009 no âmbito federal, somando-se àquelas que já haviam sido julgadas na Justiça estadual entre os anos de 2004 a 2009. Esta informação aplica-se a todas as tabelas.

Apresentamos a relação de 793 ações judiciais ambientais catalogadas em um Estado e uma cidade. A região metropolitana do Rio de Janeiro tem evidentemente um quantitativo maior de ACPs que pode ser explicado, inicialmente, pelo próprio contingente populacional. Enquanto na cidade do Rio localizam-se 6.323.446 pessoas, em todo o Espírito Santo habitam 3.512.672 pessoas, segundo o censo de 2010 feito pelo IBGE. Dentre os proponentes das ações que localizamos, sobressaem-se aqueles que foram os principais incumbidos da preservação ambiental, o MP e a sociedade civil. Em pelo menos $82,7 \%$ das ações o proponente é ou o MP ou a sociedade civil. 
Alguns trabalhos já realizados acerca do uso da ACP assinalam o baixo uso por parte das associações civis. Madeira e Nogueira realizaram um levantamento de 36 ACPs na Promotoria de Niterói em 2005, onde apenas seis foram propostas diretamente por associações civis (Madeira e Nogueira, 2007). Arantes sustentou em sua pesquisa acerca do MP que certo protagonismo desta instituição estaria fundamentado em uma concepção de que a sociedade civil seria fraca, necessitando de uma instituição forte para tutelá-la (Arantes, 1999). Conclusão que foi contestada por Maciel e Koerner (2002). Também segundo Kerche (2007:273), “o Ministério Público é o ator privilegiado para utilizar este instrumento $[\mathrm{ACP}]$ que permite judicializar uma gama imensa de assuntos e que garante a discricionariedade aos integrantes da instituição".

Nossa pesquisa não tinha como objetivo captar a percepção dos atores do MP acerca da sociedade civil, entretanto, o que é evidente nas análises qualitativas dos processos judiciais, nas entrevistas com lideranças da sociedade civil e do MP, e nos questionários aplicados é que se constitui num equívoco analisar a participação da sociedade civil no processo de judicialização apenas levando-se em conta as ACPs em que ela figura como proponente oficial. Assim como Madeira e Nogueira (2007), o que observamos é que há um grande movimento de abastecer o MP com informações, de realizar denúncias e, de forma geral, espera-se que o próprio MP tenha o trabalho de formalizar uma ação judicial. Ou seja, retornando à nossa base conceitual (fundamentada em Tarrow), a ação da sociedade civil é buscar um "aliado influente".

\section{Aliados Influentes}

Contar com o apoio de um promotor público é, certamente, dispor de um aliado influente. Ações judiciais demandam um saber específico, jurídico, uma fundamentação que raramente aqueles que não são especialistas terão. Na leitura das ACPs é evidente a diferença entre as ações propostas pelo MP e aquelas oriundas da sociedade civil. É possível perceber que muitas esbarram em problemas formais, por incompetência na escolha da comarca à qual submetem o processo, ou na equivocada identificação dos acusados etc. Assim, a principal performance (Tilly, 2006) da sociedade civil no processo de judicialização consiste em reunir evidências, provas e informações e repassá-las ao promotor que saberá com maior exatidão elaborar uma ACP. Nesse sentido, também, podemos compreender que há uma medida de "certifica- 
ção" na qual através da autoridade do Ministério Público a sociedade civil endossa sua performance de confronto (Tilly, 2005 apud Alonso, 2012).

Mas entender as formas como ocorrem vínculos informais e se estabelecem alianças desse tipo demanda uma sensibilidade aguçada e, portanto, uma metodologia etnográfica talvez fosse mais reveladora. Nesta pesquisa, no entanto, nos limitamos a recolher evidências que permitem interpretar adequadamente o "baixo" uso da ACP de forma direta pelas associações civis. Uma dessas evidências pode ser descrita como uma inclinação de promotores locais para ouvir as demandas da comunidade. Algo também descrito por McAllister (2011) e Sadeck (1997). Esta percebeu a existência de um tipo novo de promotor que atua "fora do gabinete", que sai da instituição e vai à rua (Sadeck, 1997:18). Já McAllister, em suas entrevistas com representantes de organizações ambientalistas brasileiras, chegou à constatação semelhante à nossa de que mesmo as organizações que possuem advogados em seu quadro preferem recorrer ao Ministério Público (McAllister, 2011:20). Suas conclusões argumentam que a existência do MP no Brasil dá uma característica particular à realização dos litígios ambientais neste país. Nos Estados Unidos, diferentemente, as ações judiciais são impetradas por cidadãos e grupos acionando escritórios privados de advocacia (ibidem, 2011:21).

Por parte do Centro de Apoio na área ambiental aos promotores do MP-ES (CAOA), há iniciativas de saídas regulares aos bairros de municípios da região metropolitana (Entrevistado 1, Promotora de Justiça, 2012). As visitas aos bairros estão previstas para ocorrerem semanalmente com o intuito, também, de divulgar o trabalho do MP. Além disso, há uma manifestação clara de preocupação com situações ligadas aos grandes empreendimentos no Estado do ES. Essa preocupação coincide em conteúdo com aquela observada nas falas da sociedade civil. $\mathrm{Na}$ interpretação dos próprios promotores converge o entendimento de que o "modelo de desenvolvimento" previsto para o Estado não foi dialogado com a sociedade civil e com as comunidades atingidas (Entrevistado 1, Promotora de Justiça, 2012). Na explicação de um representante de associação ambientalista do ES: "o que interessa para quem é verdadeiramente responsável pelo PIB do estado é que a questão ambiental não atrapalhe" (Entrevistado 2, Representante de associação ambientalista, 2011). Na elaboração destas interpretações, promotores públicos e sociedade civil identificam os mesmos problemas, 
estabelecem o mesmo esquema de explicação no qual a sociedade civil é vitimizada pelo poder público e pelo poder econômico - construindo, portanto, reivindicações convergentes.

Outra evidência empírica desta aliança percebida na inovação institucional criada nesta escala estadual é a inclusão da sociedade civil como fiscal de Termo de Ajustamento de Conduta (TAC_Anchieta_Samar$\left.\mathrm{Co}^{13}\right)$. Além disso, contribuem para o estreitamento dessas relações, as participações de promotores em espaços de diálogo público, como audiências públicas e o Fórum Estadual de Recursos Hídricos do ES.

Percebe-se, ademais, que as demandas da sociedade civil também ajudam o MP a estabelecer suas prioridades e metas. Isto porque a grande demanda de trabalho impõe a necessidade de realizar escolhas e, nesse momento, aqueles temas sobre os quais há um conflito mais alardeado, onde protestos, associações e a mídia estão mobilizados, irão ganhar a atenção maior de promotores (Entrevistado 3, Promotora de Justiça, 2012). Além dessas evidências, de forma complementar, sete associações ambientalistas do ES que responderam nosso questionário afirmaram terem relações formais ou informais com o MP estadual.

No Rio de Janeiro uma iniciativa amplia a possibilidade de participação e de controle do próprio MP e das decisões judiciais, trata-se do programa "Rede Ambiente Participativo" (RAP), um "portal institucional criado pelo Ministério Público (MP) para ampliar o acesso à informação e propiciar meios de participação pública na avaliação dos impactos ambientais"14. Neste portal é possível acompanhar as ACPs, inclusive averiguando a concessão de medidas liminares e as decisões dos juízes. Além disso, a análise da ACP do MP/RJ contra a alteração do traçado da Linha 4 do Metrô evidencia a ligação entre sociedade civil e MP. Nesta ACP, 18 associações de moradores subscrevem formalmente o documento que foi elaborado pelo promotor de Justiça após uma reunião pública, de sua iniciativa, onde estiveram pelo menos 48 representantes de associações civis apoiadores da causa "O metrô que o Rio precisa"15.

Em outras regiões do Brasil os vínculos também são explícitos, por exemplo, no caso dos conflitos envolvendo comunidades locais e a empresa de celulose, Veracel, na Bahia, onde várias denúncias contra a empresa vêm sendo feitas e os promotores de Justiça têm ocupado uma função inclusive de protetores, já que as lideranças sofrem constantes ameaçadas de morte pelos seus opositores. A Veracel é ré em pelo me- 
nos sete ACPs (Pinto, 2012:175). Além deste conflito, a Usina Hidroelétrica de Belo Monte, no Pará, vem causando um quantitativo importante de processos judiciais - em Pinto (2012:152) há um acompanhamento de pelo menos 15 ações contra a UHE Belo Monte. As UHE Santo Antônio e Jirau do Complexo Hidrelétrico do Rio Madeira, em Rondônia, contabilizam pelo menos sete ACPs e outros sete inquéritos civis (ibidem, 2012:162).

Mas esta proximidade entre sociedade civil e MP não é acrítica. Os coletivos mobilizados em torno dos conflitos estão atentos ao desempenho do MP e prontos para apontar suas falhas, sobretudo, quando os conflitos são encaminhados via TAC (Termo de Ajustamento de Conduta) e há uma interpretação de perda de posição, como no caso recente do mesmo conflito citado em torno da empresa Veracel. A reclamação encaminhada enquanto petição pública repudia, entre outras coisas, o TAC realizado pelo MP/BA onde se expressa o seguinte: "o MPE ignorou as entidades da sociedade civil regional que realizaram as denúncias, possibilitando o acordo mencionado no TAC e acolhendo como 'terceiros intervenientes' no processo entidades e empresas consideradas 'amigas' ou 'coirmãs' das empresas de celulose ${ }^{\prime 16}$. Voltando ao caso do Espírito Santo, apesar de o contexto apontar para uma convergência de ações, a percepção da sociedade civil é desconfiada acerca das instituições de Justiça do estado. Aspecto que aparece sempre relacionado aos escândalos recentes de corrupção do Judiciário local.

Todavia, o aspecto crítico dos coletivos com relação à atuação do MP não fere nosso argumento central, ao contrário, sugere que há o reconhecimento e monitoramento desta instituição por parte da sociedade civil, o que complexifica o aspecto relacional. Uma relação que se estabelece no discurso como confronto pode, de fato, gerar um efeito cooperativo o que significa, neste caso, impelir o MP a agir conforme o interesse da sociedade civil. Ademais, conforme Tarrow advogou, a observação da dimensão prática da ação coletiva não deve ser inferior ou secundária à dimensão simbólica, um movimento não é um mero centro cognitivo de mensagens (2009:141).

Em relação à percepção que os atores do MP fazem de si mesmos, relata-se uma diferença entre promotores e procuradores "antigos", anteriores à década de 1990, e aqueles que entram após esse período já com uma vocação para as causas coletivas.

Promotores públicos são, portanto, "aliados fortes"17, conforme as palavras de uma militante ambientalista da Rede Comuna Verde. Mas o 
que os torna "fortes" está também no próprio desenho institucional que confere ao MP uma grande autonomia combinada com poucos mecanismos de accountability. Segundo Kerche (2007:277), "o que diferencia o Ministério Público brasileiro é que, paralelamente à sua autonomia, os constituintes garantiram razoáveis graus de discricionariedade a estes atores não-eleitos do Estado". É digno de nota que muitos autores têm apontado para os perigos que uma instituição com poucos mecanismos de accountability acarreta para um sistema democrático (Kerche, 2007; Carvalho e Leitão, 2010).

Nesse sentido, o que percebemos nas entrevistas com os promotores é uma grande heterogeneidade sustentada na independência que o desenho institucional confere aos seus membros. Ou seja, a forma como o MP relaciona-se com a sociedade depende em boa parte da disposição de seus atores. Além disso, percebe-se a existência de diferentes concepções, alguns que "judicializam mais" (Entrevistado 4, Procuradora Geral da República, 2011) e outros que são mais favoráveis aos mecanismos de mediação. De toda a forma, apreende-se a grande disposição destes na realização de audiências públicas. Estas, vistas como importantes instrumentos para o desenrolar do conflito e para a formação de convicção dos próprios promotores. Não obstante, a publicização do trabalho do MP e a aproximação com a sociedade civil a transformam, também, em fonte de pressão e de fiscalização das ações da instituição. Portanto, ainda que de forma incipiente, a própria sociedade civil serviria como mecanismo informal de controle ao MP.

No debate acerca do papel do MP no processo de judicialização da política (Carvalho e Leitão, 2010; Arantes, 1999, 2002; Vianna, 2002; Sadeck, 1997; Casagrande, 2008; Maciel e Koerner, 2002) nossos dados apontam para o protagonismo evidente do MP. Além disso, são reveladores os dados acerca do "tipo de conflito" que serão expostos na próxima seção.

\section{DIVERSIDADE INSTITUCIONAL}

Conforme já explicitamos anteriormente, inserimos a categoria "diversidade institucional" como fonte de oportunidades políticas para o processo de judicialização da participação, no esquema original criado por Tarrow (ibidem). Em uma primeira vista basta constatar o próprio desenho do federalismo brasileiro, sobretudo no que se refere à área ambiental. Apesar da autonomia de estados e municípios estar limita- 
da por padrões nacionais de permissividade quanto à degradação ambiental, a maior parte das decisões ocorre no âmbito municipal e estadual. Além disso, em cada um dos níveis federativos, as decisões que afetam o meio ambiente são compartilhadas por distintas ordens institucionais, podendo os legislativos subnacionais criarem leis mais restritivas, o Executivo criar projetos e os órgãos ambientais concederem licenças ambientais. Segundo Tarrow (2009:111), “o federalismo é um convite especial aos movimentos para que transformem seus espaços em instituições, pois oferecem muitos caminhos de participação" (apud Tarrow, 1998).

No estudo desenvolvido por Ostrom (1999) e seu grupo, a proposta é de análise multiescalar das arenas de escolha nos níveis municipal, regional, estadual, federal e transnacional. Tucker e Ostrom (2009) sustentam que nos processos ambientais facilmente percebemos desdobramentos que impactam vários níveis institucionais (ibidem:36). Além de que o próprio meio ambiente enquanto "agente natural" (Little, 2006) produz fatos que movimentam distintas escalas institucionais.

Nessa mesma direção a análise de O'Donnell sobre a América Latina frisou que a heterogeneidade do Estado num sentido vertical (federalismo) e num sentido horizontal (divisão de poderes) favoreceu o desenvolvimento das "accountabilities social e judicial" que passaram a desempenhar um importante papel de controle sobre as decisões do Executivo e sobre a produção legislativa (O'Donnell, 2011:196). Assim, as instituições de controle e responsabilização desempenham um papel importante e não estão desconectadas das instituições representativas e participativas.

No caso brasileiro, na área ambiental vários mecanismos participativos estão previstos em normas constitucionais, ampliando mais ainda as possibilidades de diversidades institucionais. A Política Nacional de Meio Ambiente (PMNA) de 1981 e a Constituição de 1988 possibilitaram tanto a garantia do "meio ambiente" enquanto um valor em si positivo, quanto previram instrumentos para a construção de sistemas burocráticos e participativos de formulação das políticas ambientais e de controle e fiscalização destas - criando, assim, múltiplas arenas de decisão.

Assim, desde a década de 1980 várias iniciativas em múltiplas escalas têm criado espaços e mecanismos institucionais para solucionar con- 
flitos. Destacamos aqui o Conama (Conselho Nacional de Meio Ambiente) que foi apontado na PNMA como o principal responsável pela regulamentação das leis ambientais. Considerado por alguns como um dos "raros parlamentos ambientais do mundo" (Conama, 2008), esse conselho tem, de fato, uma estrutura sofisticada de compartilhamento de decisões entre Estado e sociedade civil e conta com poderes normativos e deliberativos através dos quais tem incrementado a legislação ambiental, tornando-a mais capaz de proteger o meio ambiente e, ao mesmo tempo, proteger as populações que dependem do meio ambiente em uma interação recíproca de sustentabilidade.

Quando há tamanha diversidade institucional, o que determinará o acionamento de uma ou outra instituição, do ponto de vista da sociedade civil, será sua percepção de eficiência e de eficácia e é aí que entram, em nosso caso de análise, o Ministério Público e o Judiciário. Ou seja, se uma instituição representativa ou participativa falha em sua capacidade de ser inclusiva e não garante que o processo decisório seja livre da dominação de interesses específicos, ela é ineficiente. Mas se ela tem pouco poder diante de outras instituições de decisão, ela é ineficaz.

Este último aspecto tem sido tratado recentemente como a questão da "efetividade da participação" (Pires, 2011). Uma das dimensões do processo de judicialização dos conflitos socioambientais está, justamente, na ineficiência ou na ineficácia de instituições participativas. Nesse sentido, o Judiciário entra como uma possibilidade de reabertura da arena de decisão de temas que já foram debatidos em instituições participativas e-por estarem dominadas por interesses específicos ou por não terem capacidade de efetivar suas decisões - não geraram o efeito esperado pela sociedade civil. Neste caso, o processo de judicialização reabre a arena de decisão.

Sendo assim, nossa análise caminha num mesmo sentido de Vianna e Burgos (2005) para os quais os procedimentos judiciais podem representar mais uma arena pública de acesso do cidadão às instituições políticas. A mobilização do direito surge, então, a partir de três significados distintos: uma medida de efetivação de uma decisão que já foi deliberada em instituições participativas; uma medida de retificação de uma decisão tomada por outra ordem institucional; e, de forma ampla, como medida de protesto, na qual se registra um descontentamento e realiza-se um confronto. Na Tabela 2, a seguir, classificamos os objetivos das ações que analisamos, com o intuito de encontrar a existência de 
um "efeito institucional" na judicialização. A medida deste efeito significa que as ações interferem na dinâmica institucional existente. Nos casos que analisamos confirma-se o sentido de "retificação" como definido acima. Isto porque boa parte das ações tem como objetivo alterar uma decisão administrativa.

Tabela 2

Objetivos das Ações Judiciais por Localidade

\begin{tabular}{l|c|c|c}
\hline $\begin{array}{l}\text { Objetivo*/ } \\
\text { Existência de “Efeito Institucional” }\end{array}$ & $\begin{array}{c}\text { Cidade do } \\
\text { Rio de Janeiro } \\
\mathbf{( \% )}\end{array}$ & $\begin{array}{c}\text { Espírito } \\
\text { Santo (\%) }\end{array}$ & $\begin{array}{c}\text { Total } \\
\mathbf{( \% )}\end{array}$ \\
\hline Revisão de ato administrativo & 6,2 & 2,9 & 9,1 \\
Conter dano ambiental & 10,8 & 6,2 & 17,0 \\
Responsabilização por dano ambiental & 2,1 & 1,4 & 3,5 \\
Responsabilização por descumprimento & 2,8 & 0,3 & 3,1 \\
de TAC/APAC & 15,6 & 0,2 & 15,8 \\
Contenção e responsabilização por dano & & 0 & 0,4 \\
ambiental & 0,4 & 0,1 & 0,1 \\
Improbidade administrativa & 0 & 2,0 & 32,3 \\
Crime ambiental & 30,3 & 0 & 18,7 \\
Vários** & 18,7 & $\mathbf{1 0 4}(\mathbf{1 3 , 1 \% )}$ & $\mathbf{7 9 3}(\mathbf{1 0 0 \% )}$ \\
\hline Não encontrado & $\mathbf{6 8 9}(\mathbf{8 6 , 9 \% )}$ \\
\hline Total de casos &
\end{tabular}

Fonte: Elaboração própria a partir de consulta às ações judiciais nos Tribunais de Justiça do ES e RJ e Justiça Federal do ES.

*A categorização aqui apresentada refere-se à caracterização formal dos litígios expressos nos textos processuais.

${ }^{* *}$ Todos os casos relacionados a esta categoria incluem necessariamente "revisão de ato administrativo".

Conforme está explícito na tabela, se somarmos as demandas das duas localidades que incluem "revisão de ato administrativo", teremos ações de um total de $41,4 \%$. Ou seja, quase metade das ações visa, pelo menos, rever decisões tomadas pela administração pública. A esse dado podemos, ainda, incluir a relação dos réus apontados nos processos e explícitas na Tabela 3, entre os quais 34,5\% referem-se ao poder público sozinho e 18,7\% incluem, além do poder público, empresas privadas. Ou seja, o poder público é réu em $53,2 \%$ das ACPs analisadas. Os dados coadunam-se à hipótese da mobilização legal como repertório de ação coletiva e à explicação aqui formulada de que as demandas da sociedade civil ao Judiciário querem a retificação de decisões consideradas injustas. 
Tabela 3

Réus das Ações Judiciais por Localidade

\begin{tabular}{l|c|c|c}
\hline Réus & $\begin{array}{c}\text { Cidade do } \\
\text { Rio de Janeiro } \\
\mathbf{( \% )}\end{array}$ & $\begin{array}{c}\text { Espírito Santo } \\
\mathbf{( \% )}\end{array}$ & $\begin{array}{c}\text { Total } \\
\mathbf{( \% )}\end{array}$ \\
\hline Poder público* & 32 & 2,5 & 34,5 \\
Concessões/Consórcios públicos & 1,5 & 0 & 1,5 \\
Vários entes públicos e privados & 15,5 & 3,2 & 18,7 \\
Entes privados & 16,5 & 5 & 21,5 \\
Empresa pública nacional & 2,3 & 0 & 2,3 \\
Pessoa física & 8,7 & 1,7 & 10,4 \\
Associação civil, recreativa ou religiosa & 3,9 & 0,3 & 4,2 \\
Outros & 0,6 & 0 & 0,6 \\
Não encontrado & 5,9 & 0,4 & 6,3 \\
\hline Total de casos & $\mathbf{6 8 9}(\mathbf{8 6 , 9 \% )}$ & $\mathbf{1 0 4}(\mathbf{1 3 , 1 \% )}$ & $\mathbf{7 9 3}(\mathbf{1 0 0 \% )}$ \\
\hline
\end{tabular}

Fonte: Elaboração própria a partir de consulta às ações judiciais nos Tribunais de Justiça do ES e RJ e Justiça Federal do ES

*Nesta categoria foram incluídos: executivos municipal, estadual e federal, o próprio administrador público e autarquias.

O significado de "retificação" é identificado na intenção evidente de modificar uma decisão tomada por órgãos ambientais, do Executivo ou do Legislativo (algumas, inclusive, que passaram por processos participativos). Exemplos nesse sentido são vastos, sobretudo, no que se refere às decisões de implementação de grandes obras, como a ampliação das plataformas da Companhia Vale do Rio Doce em Vitória (ES), da construção de portos e de "lixões". No caso do Rio de Janeiro o conflito em torno da Linha 4 do metrô é evidente medida de retificação. A "medida de protesto" justifica-se, pois, mesmo quando não se tem crença no ganho de causa, a sociedade organiza-se para registrar a sua posição de descontentamento, endereçando este a uma instituição. Querem ser ouvidos por um juiz e acreditam que de alguma forma podem, com isso, atrapalhar (ou retardar) o empreendimento em questão.

\section{Contexto de Restrições e Oportunidades Institucionais - O Caso da Ineficácia das Instituições Participativas Ambientais no ES}

Especificamente no Espírito Santo, a crescente ocupação deste território com projetos de grande impacto ambiental tem contribuído para a proliferação de conflitos desse tipo na região. Atividades diversas re- 
lativas ao extrativismo mineral e à monocultura do eucalipto ${ }^{18}$ estão entre as atividades que mais proliferaram desde a década de 1970. Além disso, nas décadas recentes, as progressivas descobertas de petróleo e da camada pré-sal vêm incrementando numericamente os empreendimentos baseados em "grandes projetos" de indústrias brasileiras e multinacionais. Segundo um levantamento dos projetos de terminais e portos (referentes aos empreendimentos em operação, em licenciamento ou previstos) realizado pela organização Conexão Abrolhos Trindade, nos próximos anos o litoral do Estado do Espírito Santo terá pelo menos 27 empreendimentos deste tipo em seus $411 \mathrm{~km}$ de extensão litorânea.

É no contexto da década de 1970 que nasce um forte movimento ambientalista local caracterizado por um conjunto de organizações que mais tarde constituíram-se no Fórum das ONGs (Lobino, 2008). Esta mobilização, inicialmente muito ligada aos problemas decorrentes da poluição na região metropolitana, passou por todas as fases, etapas e características comuns ao ambientalismo nacional no decorrer das décadas de 1980 e 1990, um processo de institucionalização em ONGs e dos repertórios de ação convertidos fortemente em participação institucionalizada em conselhos e outros colegiados. Os dois conselhos, Conselho Estadual de Meio Ambiente (Consema) e o Conselho Estadual de Recursos Hídricos, foram criados respectivamente em 1999 e 2000. Dentro da estrutura do Consema foram criados, ainda, os Conselhos Regionais de Meio Ambiente. No mesmo contexto, em 1996, o estado funda o Cadastro Estadual das Entidades Ambientalistas do Estado do Espírito Santo (CEEA), tornando-se a fonte de recrutamento de representantes da sociedade civil em conselhos ambientais.

Entretanto, apesar da existência de instituições participativas, é possível observar que estas se constituem em espaços que pouco produzem antagonismos em relação aos grandes projetos impactantes ao meio ambiente no estado. É inescapável a observação de que não estão registradas nesse cadastro das organizações civis (CEEA) aquelas que se constituem como as entidades mais críticas às políticas de desenvolvimento local que incentivam os grandes empreendimentos. Da mesma forma, observamos que as associações responsáveis por impetrar as $\mathrm{ACPs}$ que aparecem em nosso levantamento não constam no Cadastro (CEEA).

Essa constatação converge com os depoimentos de ambientalistas locais que consideram a participação no Conselho Estadual de Meio 
Ambiente pouco eficaz para contrapor-se aos interesses governamentais. Este é tomado como um espaço que acaba por legitimar os impactos e injustiças provocadas pelos projetos de desenvolvimento. Sendo assim, a ação política é francamente direcionada ao Judiciário. Segundo um dos ambientalistas ouvidos:

Hoje, ela (Associação Capixaba de Proteção ao Meio Ambiente Acapema) trabalha com a fiscalização e como uma organização que viabiliza a atuação legal na área do meio ambiente. Seria aquela instituição que, se alguém chega com uma demanda que tem que ir para juízo - seja em escala "mega" ou pequena - ela está em condição de viabilizar. É uma organização que atua em profundo entrosamento com o Ministério Público estadual e federal (Entrevistado 2, representante de associação ambientalista, 2011).

No Estado do Espírito Santo, o processo de judicialização entra no repertório de ação da sociedade civil como um recurso de retificação de processos decisórios que já foram concluídos no âmbito dos poderes Executivo e Legislativo, com o aval de instituições participativas. Segundo esses militantes, as ações judiciais entram no repertório das organizações do ES na década de 1990 e têm um processo de gradativo crescimento até hoje. Este é o caso específico da Acapema (Nascimento, 2012:260), organização fundante do ambientalismo do estado e que se caracteriza, hoje, por um ativismo judicial ${ }^{19}$.

Ressalta-se, até aqui, que o endereçamento ao Judiciário coincide com a percepção de obliteração e ineficácia das instituições participativas e não com a sua ausência ou impossibilidade de participação, como também observou Lobino (2010). "Os conselhos acabaram virando... O que era para ser um fórum que garantiria a justiça e a aplicação correta nos termos da lei do meio ambiente virou o oposto, a garantia da vitória dos interesses que não respeitam a questão ambiental" (Entrevistado 2 , representante de associação ambientalista, 2011). Sendo assim, o incentivo que cria a oportunidade está na ineficácia das instituições participativas que se tornaram legitimadoras de decisões e que, a partir desta percepção, restringem a ação política dos ambientalistas impulsionando-os para outros canais institucionais. Conforme Tilly (1978) na sua explicação sobre o surgimento de movimentos sociais, quando instituições falham e deixam de corresponder àquilo que a comunidade política espera, geram-se incentivos para novas formas de ação coletiva. Sua análise, contudo, focou a inovação no sentido de um repertório fora das instituições, aspecto que difere do nosso que apresenta o 
acionamento de uma instituição inusitada. O que percebemos, então, é que os repertórios de ação de ambientalistas no Espírito Santo encaminham-se para uma posição de confronto político. Isso se expressa nos dados referentes ao efeito institucional esperado pelas associações que moveram ACPs; todas elas requerem "revisão de ato administrativo".

Embora para propósitos de aprofundamento, tenhamos tomado especificamente o caso do Espírito Santo, observamos nas ações impetradas na cidade do Rio de Janeiro evidências fortes de enfraquecimento de Instituições Participativas ambientais estaduais. Tais evidências expressam-se na existência de duas ações civis públicas que reivindicam, exatamente, direitos relativos à participação. Uma reclama a ausência de convocação da sociedade civil para participação das reuniões do Conselho Estadual de Meio Ambiente. Outra reivindica o repasse de verbas para viabilizar a existência de associações civis ambientais. No primeiro caso, vale ressaltar que houve decisão favorável à associação, sendo o governo do estado obrigado a regularizar as convocações de reunião do conselho com o devido chamamento da sociedade civil.

Mas, além do aspecto institucional, é relevante notarmos como se constituem as estruturas de mobilização e os quadros interpretativos que balizam as buscas por judicialização.

\section{ESTRUTURAS DE MOBILIZAÇÃO E QUADROS INTERPRETATIVOS}

Segundo Klandermans (1997), quadros interpretativos da ação coletiva são transformações geradas pela elaboração de questões sociais produzidas por vários atores, entre os quais, movimentos e mídia. Tarrow a partir de Snow e Benford (1992) escreve que "os movimentos sociais se envolvem profundamente no trabalho de "nomear" descontentamentos, conectando-os a outros descontentamentos" (Tarrow, 2009:143). Para Benford e Snow (2000) os sentidos e significados das lutas de movimentos sociais não estão dados externamente à ação de seus atores. Ao contrário, os significados são formados e reformados na própria movimentação dos ativistas que, por sua vez, não estão isolados e desconectados de outros atores sociais, eles estão envolvidos profundamente com a mídia, os governos locais e o Estado (ibidem, 2000:613).

Assim buscamos analisar os temas presentes nas ACPs, procurando encontrar regularidades que permitam entender os quadros interpretativos no contexto deste repertório de ação. Mas, para tanto, não po- 
demos isolar simplesmente os conteúdos em conflito e os atores mobilizados. Nosso entendimento é que esses dois aspectos estão relacionados e contribuem para a formação de frames de ação coletiva que caracterizam o processo de mobilização legal que estamos analisando. $\mathrm{Na}$ Tabela 4 apresentamos os dados referentes ao agrupamento que fizemos na classificação do objeto dos conflitos socioambientais.

No que se refere ao tipo de conflito, as localidades apresentam diferenças relevantes. No Espírito Santo, as demandas das ações diretas das associações estão relacionadas de forma massiva à criação de grandes empreendimentos que vêm sendo implantados no Estado. Estas demandas questionam os impactos gerados, sobretudo, pela poluição do ar, a lisura no processo de licenciamento, o uso de dinheiro público com obras relativas aos empreendimentos privados, o desmatamento causado, os impactos às populações locais, indígenas, quilombolas e à pesca. Os empreendimentos questionados são, principalmente, o Complexo da Vale do Rio Doce, a Aracruz Celulose e a Companhia Siderúrgica de Ubu (CSU), entre outros.

Na cidade do Rio de Janeiro, os conflitos assumem outro desenho, evidenciando-se questões relativas à ocupação do espaço e situações de risco às populações marginalizadas. Assim, 17,7\% das ACPs estão relacionadas, especificamente, à situação de risco de deslizamento de encosta com risco à população. Esse aspecto indica ainda uma mudança na percepção dos conflitos. No levantamento realizado por Fuks, em 1991, as principais razões dos conflitos eram relativos, respectivamente, à poluição sonora, poluição do ar e desmatamento (Fucks, 2001). Além disso, o autor concluiu que a população de baixa renda tinha uma baixa participação nos conflitos judicializados (2001:88), aspecto que se opõe àquilo que evidenciamos em nossa pesquisa, onde há uma prevalência de questões relativas às populações vulneráveis impactadas por diversas causas. Além disso, a análise das associações protagonistas de ACPs revela a preponderância de associações de moradores e de pescadores como principais protagonistas, juntamente às associações ambientais.

Os sentidos que formam as percepções de injustiça nas duas localidades analisadas são parcialmente distintos. Convergem ao questionarem massivamente atos administrativos, mas refletem objetos distintos em conflito. No Espírito Santo, questiona-se a implantação de projetos econômicos de grande impacto socioambiental e que são fomen- 
Tabela 4

Tipo de Conflito das Ações Judiciais por Localidade

\begin{tabular}{|c|c|c|c|}
\hline Tipo de Conflito* & $\begin{array}{l}\text { Cidade do } \\
\text { Rio de Ja- } \\
\text { neiro }(\%)\end{array}$ & $\begin{array}{c}\text { Espírito } \\
\text { Santo }(\%)\end{array}$ & $\begin{array}{c}\text { Total } \\
(\%)\end{array}$ \\
\hline Deslizamento / situação de risco à população & 17,7 & 0 & 17,7 \\
\hline $\begin{array}{l}\text { Conflitos territoriais (ocupação e construção } \\
\text { irregular, aterro, parcelamento) }\end{array}$ & 17,3 & 2,3 & 19,6 \\
\hline Patrimônio histórico e cultural & 8,3 & 0,1 & 8,4 \\
\hline Poluição sonora & 7,8 & 0,3 & 8,1 \\
\hline Poluição da água & 6,1 & 0,6 & 6,7 \\
\hline Mineração & 1,9 & 4 & 5,9 \\
\hline Ocupação de APP ou manguezal & 2,6 & 1,4 & 4,0 \\
\hline Grandes empreendimentos & 0 & 1,4 & 1,4 \\
\hline Obras públicas irregulares & 2,3 & 0,4 & 2,6 \\
\hline Poluição produto químico & 1,3 & 0 & 1,3 \\
\hline Poluição do ar & 2,3 & 0 & 2,3 \\
\hline Radiação celular & 0,8 & 0 & 0,8 \\
\hline Poluição visual & 0,6 & 0 & 0,6 \\
\hline Lixo & 1,5 & 0,9 & 2,4 \\
\hline Maus tratos aos animais & 0,5 & 0 & 0,5 \\
\hline Desmatamentos & 0,9 & 0,5 & 1,4 \\
\hline $\begin{array}{l}\text { Participação/Empoderamento da Sociedade } \\
\text { Civil }\end{array}$ & 0,3 & 0 & 0,3 \\
\hline Importação de pneus, lixo etc. & 0,1 & 0,1 & 0,3 \\
\hline Pesca & 0,8 & 0 & 0,8 \\
\hline Prejuízo por enchente & 0,1 & 0 & 0,1 \\
\hline Outros & 3,7 & 0,3 & 4 \\
\hline Não identificado & 10 & 0,8 & 10,8 \\
\hline Total de casos & $689(86,9 \%)$ & $104(13,1 \%)$ & $793(100 \%)$ \\
\hline
\end{tabular}

Fonte: Elaboração própria a partir de consulta às ações judiciais nos Tribunais de Justiça do ES e RJ e Justiça Federal do ES.

*Para realizar esta categorização utilizamos como critério o tipo de conflito ambiental que é objeto motivacional central da ação. Tal informação foi apreendida da leitura individual de cada processo.

tados, em boa parte, por empresas multinacionais e pelo próprio Estado. Entre os réus estão o próprio poder público e a parceria entre este e as empresas. Nesse sentido, a percepção da sociedade civil acerca dos projetos de desenvolvimento existentes no Espírito Santo parece não ser muito positiva. Além disso, os sentidos do confronto que podemos apreender da análise dos dados das ações é convergente com a interpretação dos conflitos explicitada na fala dos promotores públicos entrevistados e ativistas da sociedade civil, referidas em sessão anterior. 
Um aspecto geral que também é convergente nos dois casos é que o tipo de conflito ambiental correlaciona aspectos do ambiente natural às condições sociais de vida da população. Assim, percebe-se que a legislação ambiental é acionada eminentemente para a proteção de pessoas nas suas interações com o meio, por exemplo, na busca pela preservação de atividades pesqueiras ameaçadas; para conter danos à saúde causados por efeitos tóxicos de atividades industriais; para a preservação das condições de lazer, atividades turísticas, ou modos de vida impactados pelas atividades econômicas. Na cidade do Rio de Janeiro, apesar de se destacarem as ações que visam a proteger pessoas em situação eminente de deslizamento de encostas, também encontramos dispersos em vários tipos de impactos os efeitos diversos causados por atividades industriais e extrativistas como os conflitos em decorrência dos impactos gerados pela Petrobras, com a ocorrência de "pó branco" em Duque de Caxias e a "chuva de prata" em Santa Cruz, decorrente das atividades da Companhia Siderúrgica do Atlântico (CSA), além dos demais conflitos deste empreendimento com os pescadores na Baía de Sepetiba ${ }^{20}$.

Nesse sentido, apreendem-se dois aspectos fundamentais. Primeiro, percebe-se que a legislação ambiental está cumprindo uma função que vai além de expectativas de preservação do meio natural em si, viabilizando o acesso à Justiça em sua dimensão social, sobretudo, àquela população normalmente mais vulnerável e impactada. O segundo aspecto diz respeito à formação do repertório de ação coletiva. Percebemos, pelos variados temas em conflito, uma complexa elaboração das situações de injustiça, estando estas relacionadas às atividades econômicas, às condições sociais de ocupação do espaço, aos grandes empreendimentos. Além disso, estes aspectos são fortemente relacionados aos atos do próprio poder público em uma franca ação de confronto ao Estado.

Sendo assim, a mobilização da legislação ambiental sugere uma formação de "master frames" (Benford e Snow, 2000:618), ou seja, a construção de um quadro interpretativo de amplo escopo, no qual diversas formas de injustiças podem ser relacionadas, mobilizando diversos atores. Sobre isto, ainda, Barclay et alii (2011:2) argumentam que, quando observamos a mobilização legal por parte de movimentos sociais, torna-se evidente, com frequência, que nesta interação tanto os movimentos sociais alteram seus padrões de ações em função da lei, quanto a própria lei ganha outros sentidos e usos. 
Naquilo que se refere à dinâmica de cooperação e confronto a mobilização legal é francamente uma ação de confronto. Contudo, é um repertório que se estabelece de forma institucional, o que significa que, por um lado, dinâmicas institucionais não se restringem à cooperação em instituições participativas e, por outro lado, que performances de confronto não são necessariamente informais e não institucionais.

Do ponto de vista das estruturas de mobilização, observamos que não há um específico movimento que aciona o repertório judicial. Mas verificam-se três tipos principais de mobilização associativa, tanto na cidade do Rio de Janeiro quanto no Espírito Santo. Um primeiro conjunto de ações ocorre direta ou indiretamente a partir de associações ambientalistas e ONGs; um segundo conjunto de ações tem como característica a mobilização local de pessoas através de associações de moradores; um terceiro conjunto mobiliza associações de pescadores em torno de questões locais, mas com o viés da manutenção das atividades pesqueiras. Outra configuração de mobilização que observamos envolve as associações, mas não se restringe a estas, articula a construção de redes de ativismo, informais e formais, que conectam associações locais, ONGs nacionais e internacionais, ativistas e sujeitos posicionados na universidade, em partidos políticos, em grandes ONGs, na burocracia do Estado, no MP etc.

A mobilização em redes é importante, sobretudo, para o aspecto "interativo" que conecta diversos atores e performances e cria uma interpretação integrada dos diversos impactos socioambientais, formulados enquanto injustiças. A criação do Fórum de Atingidos pelos Grandes Empreendimentos, cujo objetivo é "unificar a luta", é um exemplo dessa articulação. As redes onde encontramos relação com o repertório de judicialização são principalmente "Rede Alerta Contra o Deserto Verde" e "Articulação Internacional dos Atingidos pela Vale", além daquele acima citado. Em que pese não existir adesão total à afirmação de Gamson (1992) de que toda a ação coletiva dependeria de uma elaboração significativa de "injustiça", no caso da mobilização do direito ela é imprescindível ${ }^{21}$.

Como afirmam Benford e Snow (2000), a elaboração da interpretação de um problema ou injustiça comum não implica necessariamente ação coletiva, já que outros aspectos precisam ser elaborados, como quem são os culpados, as vítimas, quais as soluções e melhores estratégias etc. Neste sentido, mais uma vez as redes de mobilização são importantes. Sendo assim, observamos em nossos casos que as lutas se 
tornam cada vez menos estritamente locais e passam a ser compreendidas através de explicações globais, relacionadas ao sistema capitalista, ao liberalismo e à modernidade. $\mathrm{O}$ ativismo judicial entra como parte de um recurso aplicado localmente, mas elaborado enquanto estratégia transnacional ${ }^{22}$.

Em todos esses tipos de mobilização destacam-se performances associativas internas à sociedade civil e à construção de vínculos com setores do Estado. Mas, nas redes em questão, a cooperação só tem lugar se entendida a relação que se estabelece entre o militante posicionado na sociedade e o promotor de Justiça. Ainda assim, esta relação de cooperação é instável e a tônica que prevalece é a do confronto com forte crítica aos mecanismos de participação. Contudo, para entender essa dinâmica de confronto é necessário, então, admitir que ele não é para-institucional, ou anti-institucional, mas que se realiza criando vínculos e redes com a burocracia, aproximando-se da institucionalidade para lutar contra alguns de seus próprios aspectos. Paradoxalmente, uma forma de cooperação que visa o confronto.

Nas mobilizações que formam redes encontramos as performances típicas de confronto, como "bicicletadas", "marchas" etc. No sítio na internet, http://atingidospelavale.wordpress.com/ (acesso em 29/8/2012), várias campanhas por "justiça" são noticiadas no mundo todo. $\mathrm{O}$ "Boletim Justiça dos Trilhos" divulga, através desta página na internet, ganhos de causa no Judiciário, audiências públicas e discussões acerca dos marcos legais que afetam o setor. Aqui, o significado da judicialização é também de protesto, conforme as palavras de um ativista entrevistado: "o objetivo com a judicialização do conflito é criar um fato político" (Entrevistado 5, representante de rede ambientalista, 2012).

É possível constatar, portanto, que, para contrapor às injustiças elaboradas, a sociedade civil forma redes que assumem características transnacionais, tal como formularam Keck e Sikkink (1998). Elas ressignificam as demandas locais em lutas que assumem sentidos globais, antissistêmicos e contra-hegemônicos. Exemplar é o caso da formação da "Rede Alerta Contra o Deserto Verde", no Espírito Santo, que atravessa várias unidades subnacionais, posteriormente, internacionalizando-se. Esta rede inicia-se no final da década de 1990 (Lobino, 2008) em função do plantio de eucalipto em regiões do estado que são, hoje, pontos de conflitos socioambientais acirrados e que envolvem várias $\mathrm{ACPs}^{23}$. A transnacionalização ocorre, sobretudo, pelo caráter multi- 
nacional do principal opositor, na época, a empresa Aracruz Celulose S.A.

A "Rede Alerta Contra o Deserto Verde" ${ }^{24}$ inaugura (no Espírito Santo) e exemplifica bem o tipo de rede que mobiliza o direito. Ela atua em um repertório de campanhas, manifestações de rua, textos publicados, vínculos transnacionais de ativismo, "empoderamento" de populações locais, boicotes, "ações diretas" de derrubada de árvores, ações judiciais etc. Todas essas ações em situações onde há a monocultura de eucalipto. No Espírito Santo, há o envolvimento, também, das populações indígenas, Tupiniquim e Guarani, além de grupos quilombolas que realizam uma série de denúncias ao MP. As marchas coordenadas no mundo todo a partir do estabelecimento do dia 21 de setembro como o Dia Internacional contra as Monoculturas de Árvores mostram a internacionalização das ações.

Cumpre dizer ainda que, se, por um lado, há confronto com setores do Estado, por outro há parcerias, afirmando nossa observação acerca da heterogeneidade do Estado e da fluidez de lutas entre este e a sociedade civil. O Judiciário, embora sofra críticas, aparece como instância com efetividade para decidir sobre esses confrontos "de classe" conforme as palavras de sujeitos da "Rede Alerta Contra o Deserto Verde" (Lobino, 2008:105). Esta rede, embora tenha se arrefecido na última década no Espírito Santo, deixou a performance judicial como forma de mobilização, confirmando a observação de Tilly (2008) de que performances são herdadas e rearticuladas nas mobilizações presentes.

\section{CONSIDERAÇÕES FINAIS}

Nossa intenção nesta análise não reside em concluir se o processo de judicialização é "positivo" ou "negativo" para a solução dos conflitos em questão. Estamos de acordo com o entendimento de Zemans (1983) de que o uso das instituições de Justiça pode demonstrar o vigor de uma democracia tanto quanto o voto, não obstante, entendemos que há uma conexão entre o desempenho diferencial das instituições e as escolhas de estratégias de ação dos militantes. Assim, nosso foco esteve em compreender o processo de encaminhamento de demandas da sociedade civil ao Judiciário enquanto um fenômeno político que pode nos "dizer algo" sobre nosso sistema representativo e as experiências inovadoras de participação. O que concluímos é que há uma dinâmica de relação entre essas distintas ordens institucionais na qual se eviden- 
ciam os limites do sistema representativo e as ambiguidades e incertezas da participação institucionalizada, no caso da política ambiental.

Todavia, as demandas por justiça ambiental talvez sejam as mais desafiadoras para a política contemporânea sendo pouco provável que encontremos, em um único modelo de democracia, aquele capaz de dar conta dos conflitos socioambientais. Dentre os aspectos que complexificam o tema estão, por exemplo, questões relativas ao ambiente como "agente natural" onde "forças da natureza são consideradas como uma espécie de ator, no sentido de que 'agem' sobre uma realidade determinada, mas que difere qualitativamente dos atores sociais, já que não têm 'vontade' nem 'intencionalidade'" (Little, 2006:89). Existem ainda os aspectos relativos à interação do homem com a natureza através de diferentes valores ambientais - $\mathrm{o}$ ambiente pode estar subordinado ao homem sendo entendido como recurso, ou pode ser entendido como elemento indissociável do ser humano, por exemplo. Além disso, o mundo atual não compreende apenas os significados e valores modernos e ocidentais. Existem vários outros valores, demandas e significações que extrapolam as configurações institucionais ocidentais modernas e impõem mecanismos de coordenação muito mais complexos e que necessitam de um grau de flexibilização, como as demandas por formas alternativas de vida, demandas pela existência autônoma de grupos indígenas, ou o estabelecimento da própria natureza enquanto detentor de direitos, como a noção de Pachamama, em diversos países na América Latina.

Mas, entre os conflitos judicializados que observamos, há, inegavelmente, um fator que expõe a relação entre sistema político e sistema econômico. Nesse sentido, Mignolo (2008) provoca-nos para incluirmos na discussão a questão da persistência da dominação colonial através da adoção de um modelo específico de democracia intrinsecamente conectado com o sistema capitalista. Como país que surge da exploração colonial, se quisermos efetivamente ser democráticos teremos que admitir a existência legítima de distintas formas de relacionar o ambiente. Processos de complexificação e experimentação políticoinstitucional, nesse sentido, já vêm sendo realizados em países latino-americanos como a Bolívia e o Equador, ambos admitindo a legitimidade de mais de uma lógica de decisão democrática (Walsh, 2011).

O que observamos em nossa análise é que as instituições políticas democráticas tradicionais têm privilegiado a exploração dos recursos na- 
turais em favor de um conjunto específico de valores e interesses econômicos. Não obstante, surgem movimentos de resistência nas brechas ou vulnerabilidades institucionais. Nesse sentido, a judicialização analisada aqui pode ser tomada como um processo de crítica institucional, como aquilo que Goodin (1996:58) chamou de "irritantes institucionais". Uma crítica que expõe os limites das formas políticas já experimentadas e nos impulsiona a produzir incrementos nas instituições existentes e que possibilita construções paralelas capazes de desestabilizar os poderes econômicos dominantes.

Do ponto de vista das estruturas de mobilização social e ação coletiva, argumentamos que a ação civil pública e as denúncias ao MP são parte de uma cadeia de ações estratégicas da sociedade civil no que se refere às questões ambientais brasileiras. Essas estratégias envolvem a articulação de instrumentos institucionais existentes e a articulação da ação interpessoal entre sujeitos posicionados nas diversas instituições do Estado e na sociedade. Conforme explicam Silva e Oliveira (2011) a partir de Tarrow (2009), movimentos se apropriam de mecanismos institucionais, e estes reforçam as ações dos movimentos, criando ciclos que viabilizam mudanças. Nesse sentido, recorrer à Justiça tem a função de força, uma medida extrema que extrapola sua conotação estrita jurídica, ganhando significados, inclusive, de "confronto político" (McAdam, Tarrow e Tilly, 2009).

Não estamos sugerindo que a ação judicial seja $a$ solução para resolver as inúmeras situações de injustiça socioambiental, contudo, este movimento pode produzir um efeito de crítica às instituições que produzem decisões muito distantes daquilo que a sociedade civil está demandando. Ademais, conforme McCann (2010) argumenta, é necessário entender que a ação judicial tem um sentido próprio dentro dos recursos disponíveis de ação coletiva, que envolve uma dimensão instrumental e uma dimensão simbólica. Da mesma forma que Maciel conclui ao analisar o caso da Lei Maria da Penha, observamos que também no ambientalismo reside na mobilização legal uma tentativa de provocar "uma ação responsiva do Estado [...]" (Maciel, 2011:101).

Além disso, a mobilização legal também gera efeitos que redesenham as próprias instituições de justiça. Nesse sentido, o Projeto de Lei da nova Ação Civil Pública ${ }^{25}$, formulado em conjunto pelo Ministério da Justiça e diversas organizações da sociedade civil, nos oferece mais uma evidência da importância conferida pela sociedade civil a este ins- 
trumento legal e é exemplo de redesenho institucional em operação. Também revela que as organizações da sociedade civil brasileira têm um estilo de performance que se realiza, mais do que os pesquisadores estão dispostos a reconhecer, em redes interpessoais que atravessam o Estado. Os efeitos do repertório de mobilização legal ainda são pouco observados. Apesar disso, alguns pesquisadores têm concordado que é fundamental examinar as escolhas feitas pela sociedade civil, para medir o sucesso das reivindicações.

(Recebido para publicação em novembro de 2012)

(Reapresentado em março de 2013) (Aprovado para publicação em abril de 2013) 


\section{NOTAS}

1. Ação Civil Pública doravante será tratada por ACP.

2. Inicialmente tratamos a questão como "judicialização dos conflitos", mas, após alguma discussão durante a participação no GT da Anpocs, "Judiciário e política", optamos por não utilizar a palavra "judicialização" tendo em vista que o debate ao qual está comumente associada (ver Maciel e Koerner, 2002) foge ao sentido que queremos dar, qual seja, do uso do recurso judicial como estratégia de luta da sociedade civil. Sendo assim, o conceito de "mobilização do direito" de Zemans (1983) está mais apropriado para o sentido que estamos propondo.

3. Apesar de reconhecermos que Tilly rechaçou o conceito de "sociedade civil", preferindo o uso de "sociedade política", optamos pela utilização dessa categoria, porém, sem toda a carga normativa associada ao conceito. Neste sentido, referimo-nos a um conjunto abrangente de atores que não representam o Estado nem os interesses do mercado e que estão mobilizando a lei. Incluímos neste recorte atores mobilizados por causas coletivas, tais como associações civis, movimentos sociais, ONGs, sindicatos, ativistas em geral, redes etc. Ademais é preciso lembrar que realizamos, aqui, um esforço de entender um fenômeno que atravessa vários campos de estudo sobredeterminados por aspectos da participação política, das relações interinstitucionais, da judicialização da política etc., sendo necessário certo ecletismo conceitual. Obviamente que não nos escapam as disputas envolvendo o conceito de "sociedade civil" nas teorias da ação coletiva, como bem foi levantado por Alonso (2009).

4. A pesquisa que origina este trabalho conta com auxílio financeiro do Conselho Nacional de Desenvolvimento Científico e Tecnológico (CNPq).

5. No banco de dados, preservamos os registros da origem do dado e da numeração de cada ação judicial o que permite a conferência acerca da fidedignidade da classificação.

6. Os dados referentes às ACPs são escassos. Não há um sistema de consulta no MP aberto ao público e o relato de promotores e procuradores é de que eles não conhecem, de forma geral, o perfil do universo das ACPs. Apesar disso, é consensual a ideia de que há uma ampliação muito grande na demanda ao MP por conflitos socioambientais.

7. As entrevistas possuem registros sonoros e estão transcritas e arquivadas, em formato digital, juntamente com os questionários e os documentos consultados.

8. Tal registro pode ser observado no sítio da organização na internet: http:/ / amarnatureza.org.br/site/acoes-civis-publicas-acps-propostas-pela-amar-isolada-ou-conjuntamente-em-tramitacao-em-primeira-instancia,134/ (acesso em 25/02/2013).

9. Por "procedimentos" estamos entendendo de forma ampla as denúncias, representações, ações que demandaram alguma providência do MPF. O quantitativo foi medido pela própria $4^{a} \mathrm{CCR}$ e refere-se ao arquivamento de denúncias e processos, revisão de competência, TAC e recurso de decisão. Os dados estão disponíveis em: http:/ / 4ccr.pgr.mpf.gov.br/documentos-e-publicacoes/relatorios/relatorios (acesso em 03/02/2011)

10. Recentemente Alonso (2012) realizou um amplo apanhado do conceito de "repertório" de Tilly, sublinhando suas variadas nuanças. Em Bringel (2012) é possível encontrar, ainda, outros aspectos da teoria desenvolvida pelo mesmo autor. 
11. Neste aspecto, queremos, justamente, levantar a mobilidade ou o caráter de flexibilidade do aspecto institucional. Nossa intenção é a de evitar a crítica dirigida a Tilly por enfatizar aspectos institucionais e com isso tornar a análise tendencialmente estática (Bringel, 2012:50).

12. Gamson (1992) defendeu que toda articulação e elaboração de ação coletiva passa por uma interpretação de "injustiça", aspecto sobre o qual Benford e Snow (2000) discordaram.

13. Disponível em: http://www.mpes.gov.br/conteudo/CentralApoio/conteudo5. asp? cod_arquivo $=2807 \&$ cod_centro $=10($ acesso em $03 / 03 / 2012)$

14. Texto de apresentação do RAP. Consultado no site: http://rap.gov.br/ (acesso em 01/03/2013).

15. O documento pode ser acessado no link: https://docs.google.com/file/d/ 0BxSgcH3QIaqxM2MyOThhZGMtYjNiNS00MmZkLWJhNDgtY2IwYmVmODRk $\mathrm{Njlm}$ /edit (acesso em 01/02/2013)

16. A petição pública pode ser acessada online no endereço: http://www.peticaopublica.com.br/PeticaoVer.aspx?pi=P2012N24532 (acesso em 01/02/2013)

17. Disponível em: http://www.redecomunaverde.org/rede/index.php?option= com_content\&view $=$ category $\& l$ layout $=$ blog $\& i d=30 \& I t e m i d=59$ (acesso dia 10/06/2012).

18. Além da exploração, propriamente dita, dos recursos naturais há uma proliferação de portos, ferrovias e indústrias de suporte que surgem em decorrência dessas atividades.

19. Nossa observação acerca do descrédito conferido às instituições participativas e o uso da judicialização como repertório de ação converge com a análise recente feita por Nascimento (2012) acerca da Acapema.

20. Muitas das ACPs propostas por pescadores correm em segredo de justiça e por isso, como não tivemos acesso ao processo, não aparecem nas estatísticas que apresentamos. Apesar disso, promotores e lideranças do Movimento dos Pescadores e Pescadoras Artesanais com os quais conversamos relatam a existência de inúmeras ações judiciais na região.

21. Nesse sentido, o aumento da mobilização legal seria um indicador também para a prevalência do componente de significação "injustiça" na elaboração das ações coletivas.

22. Durante a Cúpula dos Povos, por exemplo, observamos o Collectif Alternative Biopiraterie que se reuniu em atividades autogestionadas para, entre outras coisas, discutir estratégias de combate à biopirataria e aos transgênicos, no mundo todo, entre as quais ações judiciais ganharam destaque. Outro exemplo é a mobilização dos atingidos por petróleo e gás, Oilwatch, que articula grupos em todos os países em que existe exploração de petróleo e gás.

23. Em 2002 a Acapema já havia entrado com uma ACP questionando a ausência de licença ambiental para atuação da Aracruz Celulose na região (Lobino, 2008).

24. Hoje chama-se apenas Rede Alerta.

25. O Projeto de Lei 5.139/2009 propõe o redesenho institucional. Entre as propostas de modificação destacamos a ampliação do acesso e a inclusão de regra que dá prioridade de julgamento à ACP nos tribunais. O PL encontra-se em análise na Câmara dos Deputados. 


\section{REFERÊNCIAS BIBLIOGRÁFICAS}

ABERS, Rebecca Neaera e BÜLOW, Marisa von. (2011), “Movimentos Sociais na Teoria e na Prática: Como Estudar o Ativismo através da Fronteira entre Estado e Sociedade?" Revista Sociologias, vol. 13, pp. 52-84.

ALONSO, Angela. (2009), "As Teorias dos Movimentos Sociais: Um Balanço do Debate”. Lua Nova, vol. 76, pp. 49-86.

. (2012), "Repertório, segundo Charles Tilly: História de um Conceito". Revista Sociologia \& Antropologia, vol. 2, no 3, pp. 21-41.

; COSTA, Valeriano e MACIEL, Débora. (2007), “Identidade e Estratégia na Formação do Movimento Ambientalista Brasileiro". Novos Estudos CEBRAP, no 79.

ARANTES, Rogério Bastos. (1999), “Direito e Política: O Ministério Público e a Defesa dos Direitos Coletivos". Revista Brasileira de Ciências Sociais, vol. 14, no 39.

. (2002), Ministério Público e Política no Brasil. São Paulo, Educ/Sumaré.

AVRITZER, Leonardo e PEREIRA, Maria de Lourdes Dolabela. (2005), “Democracia, Participação e Instituições Híbridas". Teoria E Sociedade, número especial, pp. 16-41.

BARCLAY, Scott et alii. (2011), "Two Spinning Wheels: Studying Law and Social Movements", in A. Sarat (org.), Special Issue: Social Movements/Legal Possibilities. Bingley, Emerald Group Publishing Limited.

BENFORD, Robert D. e SNOW, David A. (2000), "Framing Processes and Social Movements: An Overview and Assessment". Annual Review of Sociology, vol. 26, pp. 611-639.

BRINGEL, Breno. (2012), “Com, Contra e para Além de Charles Tilly: Mudanças Teóricas no Estudo das Ações Coletivas e dos Movimentos Sociais". Revista Sociologia \& Antropologia, vol. 2, no 3, pp. 43-67.

CARVALHO, Ernani e LEITÃO, Natália. (2010). “O Novo Desenho Institucional do Ministério Público". Revista Direito GV, vol. 6, no 2, pp. 399-422.

CASAGRANDE, Cássio. (2008), Ministério Público e Judicialização da Política: Cinco Estudos de Caso. Porto Alegre, Sérgio Antônio Fabris Editor.

CONSELHO NACIONAL DO MEIO AMBIENTE. (2008), Resoluções do Conama: Resoluções Vigentes Publicadas entre Julho de 1984 e Novembro de 2008. 2a ed. Brasília, Conama.

ENGELMANN. Fabiano. (2006), “Internacionalização e Ativismo Judicial: As Causas Coletivas". Lua Nova, no 69, pp. 123-146.

FUKS, Mario. (2001), Conflitos Ambientais no Rio de Janeiro: Ação e Debate nas Arenas Públicas. Rio de Janeiro, Editora UFRJ.

GAMSON, William A. (1992), Talking Politics. New York, Cambridge University Press.

GOFFMAN, Erving. (1974), Frame Analysis: An Essay on the Organization of the Experience. New York, Halper-Colophon.

GOODIN, Robert E. (1996), Teoría del Diseño Institucional. Barcelona, Editorial Gedisa.

JENSEN, Angie. (2010), “Making Environmental Law Matter”. Advocate, vol. 25, no 2, pp. 25-29. 
KLANDERMANS, Bert. (1997), The Social Psychology of Protest. Oxford, Blackwell.

KECK, Margareth e HOCHSTETLER, Kathryn. (2007), Greening Brazil: Environmental Activism in State and Society. Durham, Duke University Press.

KECK, Margareth e SIKKINK Kathryn. (1998), Activists Beyond Borders: Advocacy Networks in International Politics. Ithaca, NY, Cornell University Press.

KERCHE, Fábio. (2007), “Autonomia e Discricionaridade do Ministério Público no Brasil". Dados, vol. 50, no 2, pp. 259-279.

LITTLE, Paul Elliot. (2006), “Ecologia Política como Etnografia: Um Guia Teórico e Metodológico". Horizontes Antropológicos, vol. 12, no 25.

LOBINO, Camilla Ferreira. (2008), As Entidades Associativas Não-governamentais e o Monocultivo do Eucalipto no Espírito Santo. Dissertação de Mestrado em Planejamento Urbano e Regional, Programa de Pós-Graduação em Planejamento Urbano e Regional, Universidade Federal do Rio de Janeiro (UFRJ/IPPUR), Rio de Janeiro.

MACIEL, Débora Alves. (2011), “Ação Coletiva, Mobilização do Direito e Instituições Políticas: O Caso da Campanha da Lei Maria da Penha". Revista Brasileira de Ciências Sociais, vol. 26, no 77 .

e KOERNER, Andrei. (2002), "Sentidos da Judicialização da Política: Duas Análises". Lua Nova, no 57.

MADEIRA FILHO, Wilson e NOGUEIRA, Roberta Ponzo. (2007), “Atuação do Ministério Público e da Sociedade Civil Organizada no Acompanhamento e Propositura das Ações Civis Públicas Ambientais no Município de Niterói-RJ". Âmbito Jurídico, vol. X, no 40 .

MCADAM, Doug; TARROW, Sidney e TILLY, Charles. (2009), "Para Mapear o Confronto Político". Lua Nova, no 76.

MCALLISTER, Lesley K. (2008), Making Law Matter: Environmental Protection and Legal Institutions in Brazil. Stanford, CA, Stanford University Press.

(2011), "Environmental Advocacy Litigation in Brazil and the United States". Journal of Comparative Law, vol. 6, № 2 .

MCCANN, Michael. (2010), “Poder Judiciário e Mobilização do Direito: Uma Perspectiva dos 'Usuários'”. Anais do Seminário Nacional sobre Justiça Constitucional. Seção Especial da Revista Escola da Magistratura Regional Federal da 2a. Região/Emarf, pp. 175-196.

MIGNOLO, Walter. (2008), “Hermenéutica de la Democracia: El Pensamiento de los Límites y la Diferencia Colonial”. Tabula Rasa, Bogotá, no 9 .

NASCIMENTO, Euzeneia Carlos do. (2012), Movimentos Sociais e Instituições Participativas: Efeitos Organizacionais, Relacionais e Discursivos. Tese de Doutorado, Programa de Pós-Graduação em Ciência Política, Universidade de São Paulo, São Paulo.

O'DONNELL, Guillermo. (2011), Democracia, Agência e Estado: Teoria com Intenção Comparativa. São Paulo, Paz e Terra.

OLIVEIRA, Wilson. (2008), “Gênese e Redefinições do Militantismo Ambientalista no Brasil". Dados, vol. 51, no 3, pp. 751-777.

DADOS - Revista de Ciências Sociais, Rio de Janeiro, vol. 56, nำ2, 2013 


\section{Cristiana Losekann}

OSTROM, Elinor. (1990), Governing the Commons: The Evolution of Institutions for Collective Active. New York, Cambridge University Press.

e TUCKER, Catherine. (2009), “Pesquisa Multidisciplinar Relacionando Instituições e Transformações Florestais", in E. Moran e E. Ostrom (orgs.), Ecossistemas Florestais: Interações Homem-ambiente. São Paulo, Editora Senac/Edusp, pp. 109-138.

PINTO, João Roberto Lopes (org.). (2012), Ambientalização dos Bancos e Financeirização da Natureza. Brasília, Rede Brasil.

PIRES, Roberto (org.). (2011), Efetividade das Instituições Participativas no Brasil: Estratégias de Avaliação. Brasília, IPEA, vol. 1.

SADECK, Maria Tereza (org.). (1997), O Ministério Público e a Justiça no Brasil. São Paulo, Sumaré/Idesp.

SILVA, Marcelo Kunrath e OLIVEIRA, Gerson de Lima. (2011), “A Face Oculta(da) dos Movimentos Sociais: Trânsito Institucional e Intersecção Estado-Movimento: Uma Análise do Movimento de Economia Solidária no Rio Grande do Sul". Sociologias, vol. 13, no 28 .

SNOW, David A. e BENFORD, Robert D. (1988), “Ideology, Frame Resonance, and Participant Mobilization". International Social Movement Research, vol. 1, pp. 197-218.

TARROW, Sidney. (1998), “The Very Excess of Democracy': State Building and Contentious Politics in America", in A. Costain e A. McFarland (orgs.), Social Movements and American Political Institutions. Boulder, Col., Rowman and Littlefield, cap. 2.

(2009), Poder em Movimento: Movimentos Sociais e Confronto Político. Petrópolis, Vozes.

TILLY, Charles. (1977), "Getting it Together in Burgundy". Theory and Society, no 4, pp. 479-504.

(1978), From Mobilization to Revolution. Reading M.A., Addison-Wesley.

. (2006), Regimes and Repertoires. Chicago, University of Chicago Press.

(2008), Contentious Performances. New York, Cambridge University Press.

e TARROW, Sidney. (2007), Contentious Politics. London, Paradigm Publishers.

VIANNA, Luiz Werneck (org). (2002), A Democracia e os Três Poderes no Brasil. Belo Horizonte/Rio de Janeiro, Editora UFMG/IUPERJ/FAPERJ.

VIANNA, Luiz Werneck e BURGOS, Marcelo Baumann. (2005), “Entre Princípios e Regras: Cinco Estudos de Caso da Ação Civil Pública”. Dados, vol. 48, no 4, pp. 777-843.

; BURGOS, Marcelo Baumann e SALLES, Paula Martins. (2007), “Dezessete Anos de Judicialização da Política". Tempo Social, vol. 19, no 2, pp. 39-85.

WALSH, Catherine. (2008), “Interculturalidad, Plurinacionalidad y Decolonialidad: Las Insurgencias Político-epistémicas de Refundar el Estado”. Tabula Rasa, no 9.

ZEMANS, Francês Kahn. (1983), “Legal Mobilization: The Neglected Role of the Law in the Political System". The American Political Science Review, vol. 77, no3, pp. 690-703. 


\section{ABSTRACT \\ Mobilization of Law as a Repertoire of Collective Action and Institutional Critique in the Brazilian Environmental Field}

The aim of this article is to characterize legal mobilization as a repertoire of social action in the Brazilian environmental field, analyzing how and why court action becomes a repertoire of collective action. The authors present data on the use of collective action, based on research using quantitative and qualitative methods. The main conclusions are that legal mobilization occurs through flows of interpersonal action between actors from government and civil society and that the perception of deficiency in representative and participatory institutional processes is an incentive for legal action. The authors further suggest that mobilization of legal institutions as a repertoire of collective action can generate a process of institutional critique.

Key words: mobilization of law; repertoires of collective action; political participation; environmentalism

\section{RÉSUMÉ \\ Mobilisation du Droit comme Répertoire de l'Action Collective et Critique des Institutions dans le Domaine de l'Environnement au Brésil}

Dans cet article, on cherche à caractériser la mobilisation légale comme une action collective concernant l'environnement au Brésil, à partir de l'analyse des motifs et de la façon dont le choix de la voie judiciaire devient un répertoire d'actions collectives. On présente des données sur le recours à l'Action Civile Publique d'après une recherche à partir de méthodes quantitatives et qualitatives. Les résultats montrent surtout que la mobilisation légale se fait à travers des courants d'action interpersonnels entre acteurs de l'état et de la société civile, l'impression de défaillance concernant les processus institutionnels représentatifs et participatifs menant à la mobilisation légale. On suggère que la mobilisation des institutions de justice en tant que répertoire d'actions collectives peut engendrer un processus de critique des institutions.

Mots-clés: mobilisation du droit; répertoires d'actions collectives; participation politique; environnement 